\title{
JOURNAL.RU
}

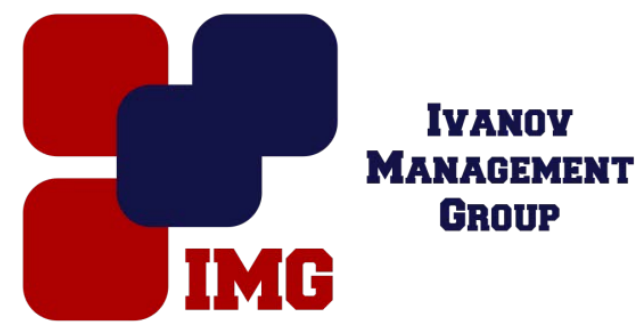

Тарановская Е.А., Гончаров В.О., Туркова Н.Ю., Самигуллин Н.Р.

Оренбургский государственный университет Оренбург, Россия

doi: 10.18411/lj-28-02-2017-3-10

idsp 000001:1j-28-02-2017-3-10

\section{Устройство нежестких дорожных одежд с применением щебеночно- мастичного асфальтобетона (ЩМА)}

\section{Аннотация}

В данной статье рассматривается применение ЩМА с добавкой Топсел. Изложены основные преимущества щебёночно-мастичного асфальтобетона, широко применяемого в дорожном строительстве (экономичность, отсутствие требований к специальной технологии укладки).

Ключевые слова: асфальтобетонная смесь,битум, восковая смесь, щебеночно-мастичный асфальтобетон,стабилизирующие добавки, “Топсел”.

Увеличение количества транспорта в нашей стране приводит к повышению интенсивности движения и увеличение нагрузки на дорожное покрытие. Повышение интенсивности движения транспортными средствами предъявляет повышенные требования к транспортно-эксплуатационным показателям автомобильных дорог, которые обеспечиваются в процессе строительства. В России за последние 5 лет при устройстве покрытий дорог с высокой грузонапряженностью стали модифицировать не только битумы с помощью полимерных добавок и добавок нефтехимической переработки, но и вводить новые составляющие в сам асфальтобетон. Самый известный материал, изготовленный по таким технологиям - щебеночно-мастичный асфальтобетон.

ЩМА - это щебеночно-битумная смесь, состоящая из щебеночного скелета, в котором все пустоты между крупным щебнем заполнены смесью битума с дробленым песком (битумная мастика). Такая структура обеспечивает передачу нагрузки с поверхностных слоев в нижние через контактирующие друг с другом непосредственно, отдельные крупные частицы каменного материала, что существенно сказывается на снижении деформаций слоя, оказывая распределение нагрузки по всем направлениям покрытия[1]. Для изготовления ЩМА используется щебень соответствующих фракций (5-10, 10-15, 15-20 мм) и плотные трудношлифуемые горные породы, которые обладают отличным сцеплением с вяжущим битумом. Кроме того в производстве также используется щебень из металлургических шлаков, который соответствует общим техническим требованиям. Он помогает обеспечивать отличные фрикционные свойства, а также 
сдвигоустойчивость, водонепроницаемость и шероховатость устраиваемого покрытия, для безопасного автомобильного движения[2].

Стоимость обслуживания верхнего слоя дорожного покрытия, изготовленного из ЩМА, в 2 раза ниже стоимости обслуживания слоя, изготовленного из асфальтобетона, из-за большей стойкости против колееобразования, меньшей склонности к образованию трещин и большей деформативности(рис.1)
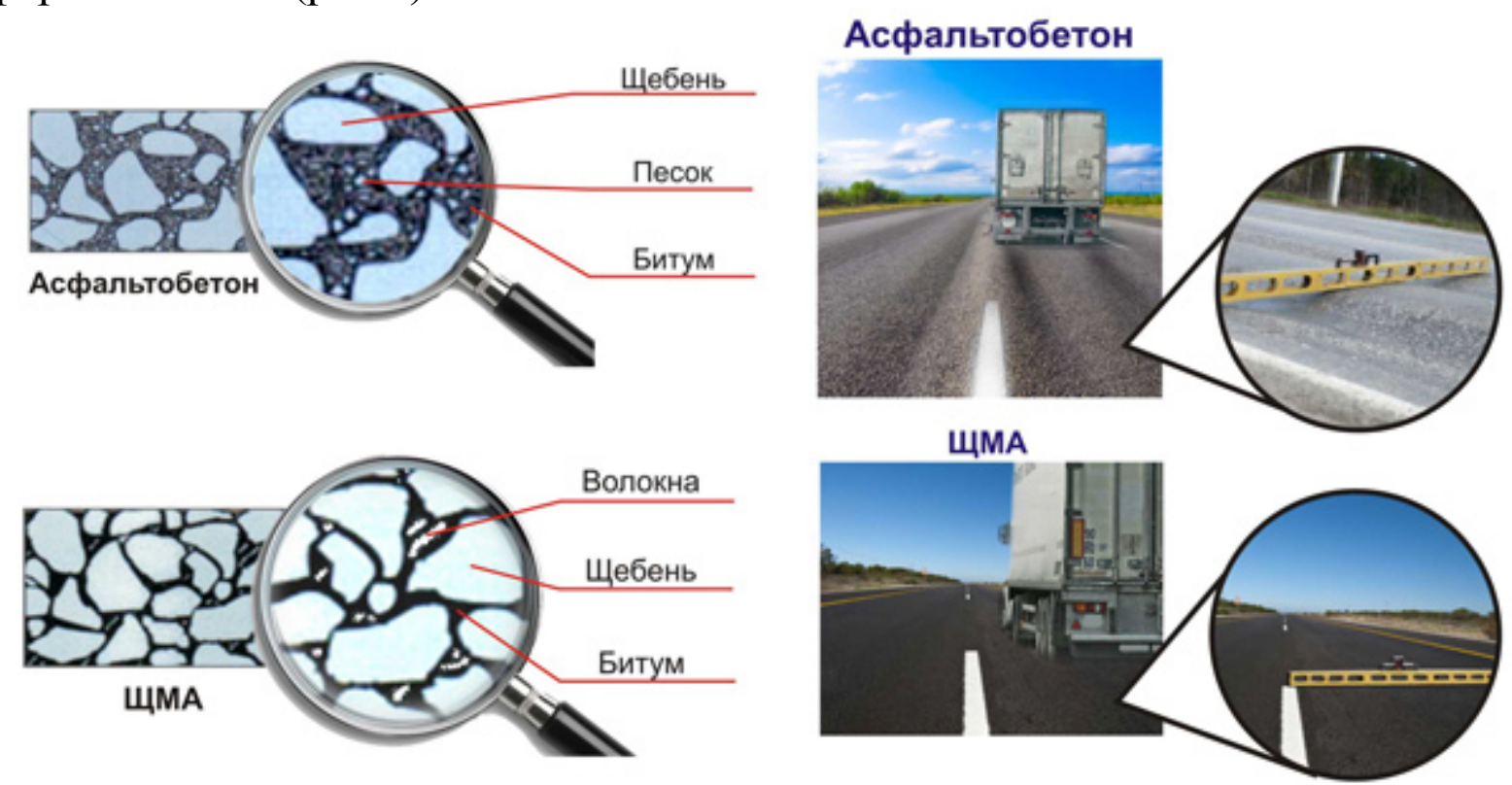

Рисунок 1-Сравнение традиџионного асфальтобетона и ЩМА

По составу своих компонентов имеет сходство с другими горячими асфальтобетонными смесями. Проблемой традиционных горячих асфальтобетонных смесей является склонность к сегрегации (взаимоотделение входящих в состав компонентов, расслоение) на всех технологических переделах. В связи с этим следует отметить, что у смесей ЩМА отсутствуют признаки сегрегации в процессе приготовления, хранения, транспортирования и укладки[3].

Характерное отличие ЩМАот других горячих асфальтобетонных смесей жесткая каркасная структура в слое покрытия, а также наличие в его составе применяемых специальных стабилизирующих добавок[4].

Главная задача таких добавок - препятствовать стеканию с ЩМА битумного вяжущего при транспортировке, производстве и эксплуатации.В последнее время для достижения оптимального показателя стекания смеси в нее вводят импортную добавкуТопсел.

Стабилизирующая добавка «Топсел» - это гранулированный материал, который состоит из целлюлозного волокна (90-93\%) и восковой смеси (710\%).Последняя служит оболочкой гранулы.Расход добавки является одним из наименьших по сравнению с другими - 0,28-0,32\% от массы ЩМА.

Восковая смесь ни сколько не ухудшает характеристики ЩМА, даже наоборот - улучшает их адгезионные свойства в отношении каменных материалов.

Стабилизирующая добавка «Топсел» характеризуется следующими показателями:

- термостойкость при нагревании до $250{ }^{\circ} \mathrm{C}$; 
- беспроблемное и эффективное выделение волокон целлюлозы из гранул;

- удобство транспортировки и возможность автоматического дозирования;

- неслеживаемость при хранении.

Дозирование стабилизирующей добавки может осуществляться автоматически из силосной башни или контейнера[5].Спецификой получаемой смеси ЩМА является её более высокая, по сравнению с обычными асфальтобетонными смесями, температура приготовления. Это связано с температурной чувствительностью смеси и с тем, что ЩМА укладывается в основном тонкими слоями, склонными к быстрому охлаждению. Время хранения смеси в бункере не должно превышать получаса. Щебеночно-мастичные асфальтобетонные смеси укладывают на предварительно обеспыленную поверхность, при наружной температуре не менее $+5^{\circ} \mathrm{C}$ весной и $+10^{\circ} \mathrm{C}$ осенью. Горячая смесь укладывается и уплотняется обычными асфальтоукладчиками и гладковальцовыми катками.

Если согласно лабораторным исследованиям срок службы обычного дорожного покрытия 5-6 лет, то при использовании добавки «Топсел» в тех же условиях покрытие может простоять в 2-3 раза дольше[6].Актуальность этого материала обусловлена его специфическими транспортно-эксплуатационными показателями, включая комфортабельные и безопасные ездовые качества, сопротивляемость внешним воздействиям, стабильность и долговечность слоя,тем самым способствует решению одной из самых актуальных проблем в области дорожного строительства.На основании вышеизложенного можно сделать вывод о рациональности, экономичности, удобстве применения ЩМА при выполнении дорожно-строительныхработ.

\section{Литература}

1. Арутюнов $\quad$ В. Г., Первый опыт строительства покрытий из щебеночно-мастичного асфальтобетона в России // Дороги России XXI века. - 2002. - № 3. - С. 58 - 61.

2. ГОСТ 31015-2002. Смеси асфальтобетонные и асфальтобетон щебеночно- мастичный.

3. Носов В. П., Оценка экономической эффективности применения укрепленных грунтов в основаниях дорожных одежд / В. П. Носов, С. С. Фролкина. - Сборник научных трудов Всероссийской научно практической конференции. 15-16 мая - Казань: КГАСУ, 2008. $-360 \mathrm{c}$.

4. Официальный сайт главного управления дорожного хозяйства Оренбургской области. Электронный ресурс: точка доступа http://www.orendor.ru/shma.htm

5. Полимерный модификатор для стабилизирующей добавки к щебеночно-мастичному асфальтобетону / КемаловР.А., Идрисов М.Р., КемаловА.Ф., Фаттахов Д.Ф. // Вестник Казан.технол. ун-та. - 2011, №9. - С. 229-232.

6. Жураускас А.В., Акулов А.П. Щебеночно-мастичный асфальтобетон. Теоретические основы, практика применения // Строительные материалы. - 2003. - №1. - С. 22. 